\title{
Analyzing 'needs' for designing a specific English language course for medical students in Bangladesh LIZA SHARMIN
}

\begin{abstract}
ESP (English for Specific Purposes) ensures designing courses to meet learners' needs. Two vital devices of determining the needs are target needs and learning needs. The term target needs refers to what learners need to do in the target situation. It consists of three components- necessities, lacks, and wants. Learning needs are what learners need to do in order to learn. In designing an English course for the medical students, the research has focused on target needs and learning needs along with necessities, lacks, and wants. The medical students are really motivated by their subject specific texts. Most of the students suffer from the lack of adequate vocabulary. Their knowledge in the major areas of English grammar such as tense system, concept of voice, the syntax etc. is not sufficient. Their lack of the knowledge of the language is one of the prime reasons for their not being able to speak and write correctly and smoothly. A specific English language course can solve the problems by bridging their area related knowledge with their English language proficiency.
\end{abstract}

\section{Introduction:}

Today, global understanding as well as intellectual and interpersonal communication can be ensured through the practice of English since it is widely used as an international language. As a foreign / second language, English is extremely popular and is in great demand for some specific purposes, besides the practice of English literature and communication.

Now-a-days special English language courses are being used in all types of technical and business English education. These specific English language courses are the issues and concerns of English for Specific Purposes (ESP), which belong to the area of English language Teaching (ELT). ESP is considered as Applied ELT, 
since the goals and objectives and the syllabus of such a course are determined by the needs of a specific group of learners. ESP is divided into EAP (English for Academic Purposes) and EOP (English for Occupational Purposes). Again, EOP covers the area of business English, professional English (e.g. English for doctors, lawyers, etc.) and vocational English (e.g. English for tourism, nursing, aviation, etc).

ESP is a highly effective approach to language teaching in which all decisions as to content and method are based on learners' reason for learning. On the basis of the professional requirements, learners need particular course designing to develop and practice English language skills. The materials for teaching language should also be relevant for learners with the area or field they study or practice. On the basis of needs, the designer will specify the goals and objectives of a course. The paper will focus on how 'needs' can be analyzed for developing a specific course for the medical students in Bangladesh.

For more than nine years, I have been teaching general English language course to the medical students at Gono Bishwabidyalay. While teaching, I found that there was a gap between their target area and English language. They cannot apply the knowledge they acquire on English language to the medical context. For example, in an English language class, when they are asked to solve some exercises on active and passive voices, they can solve properly. But when they define terms like hypertension, or nervous system, they confidently use called/call/ calls instead of is/ are called. The medical students are really motivated by their subject specific texts. It is my assumption that a specific English language course can solve the problem by bridging their area-related knowledge with their English language proficiency.

The first major and basic step for designing a specific course is 'needs analysis'. It is a process to specify or determine exactly why the learners need English language proficiency. Hutchinson and Waters (1987) define needs in term of 'target needs' (i.e. what the learner needs to do in the target situation) and learning needs (i.e. what the learners need to do in order to learn) (p.54). Dudley Evans, T., \& St. John, M. (1998), opine "the best methodology for specifying the target need of any particular group of students is to use such methods as questionnaires, follow-up 
interviews, collection of authentic work place texts and visit to the workplaces" (p.67).

\section{Target Needs}

'Target needs' is defined as what the learner needs to do in the target situation. Hutchinson and Waters have considered the 'Target needs' as an umbrella term, which in practice hides a number of important distinctions. It is more useful to look at the target situation in terms of (a) necessities, (b) lacks, and (c) wants.

\section{(a) Necessities}

The term 'Necessities' is most essential to identify the target needs for an ESP syllabus. In ESP, usually necessities are the category of needs determined by the demands of the target situation, that is, what the learner has to know in order to function effectively in the target situation. The research has specified the 'necessities' of English language proficiency for the medical students. English is the medium of instruction in all the medical colleges in Bangladesh. So, the students must depend on English language skills due to a number of reasons:

-Medical books are written in English, and no standard or equivalent translations of these are available. So, they need to go through the books that are all in English.

-Medical journals and research reports are usually published and/or interpreted in English. To enrich their knowledge, they must keep themselves in touch with these publications.

-They are to attend seminars on newly identified diseases or recently invented medicines and/or instruments. To attend and understand the theme and also for further information, they need to have a strong command over English language.

-Bulk of up-to-date data and information on the internet is available in English. To run with the current global world, they must update their 
knowledge by collecting resources from the internet. And, for this purpose, they need proficiency in English language.

-The vital portion of a lecture in classrooms is delivered in English. Sometimes, visiting professors or specialists from foreign countries are appointed as course teachers. To follow their lectures, they must have a good command over English language.

-Students are asked to write their answers in English in examination hall.

-Students need to take oral tests in English.

-In these days of globalization, students of medical colleges often come across classmates who come from abroad. For communication, they must choose English.

-For higher studies abroad, students hardly have any other way open before them except English as the medium of instruction and education.

-In professional life, students usually need to communicate with both foreign experts and patients through English language. Moreover, to receive or give instructions and write prescriptions and certificates, they need to know English.

The students also need to have a good command of the functional, structural, and lexical elements which are commonly used in the situation identified.

Munby's (1978) Communicative Syllabus Design is considered as the most detailed and well-known research oriented work for 'analyzing needs'. The set of procedures for 'analyzing needs' proposed by Munby is called Communicative Needs Processor (CNP). Using the following model from Munby, we can analyze the necessities of English language proficiency for the medical students: 
Sample

'communicative

activities'
Related

'micro function'
Language form

(productive)

\begin{tabular}{|c|c|c|}
\hline $\begin{array}{l}\text { 1. To attend lecture } \\
\text { class }\end{array}$ & $\begin{array}{l}\text { 1. Listen and } \\
\text { comprehend } \\
\text { 2. Ask question } \\
\text { 3. Answer }\end{array}$ & $\begin{array}{l}\text { 1. The lecture on blood circulation } \\
\text { system was complicated but } \\
\text { interesting. } \\
\text { 2. Excuse me sir, would you please } \\
\text { repeat the functions of pulmonary } \\
\text { artery and vein? } \\
\text { 3. Yes sir, it carries oxyzanated } \\
\text { blood. }\end{array}$ \\
\hline $\begin{array}{l}\text { 2. To attend Viva- } \\
\text { voce }\end{array}$ & $\begin{array}{l}\text { 1.Listen and understand } \\
\text { the question } \\
\text { 2. Answer } \\
\text { 3. Request to get clues }\end{array}$ & $\begin{array}{l}\text { 1. Can a mole be cancerous? } \\
\text { 2. Yes, when it is asymmetrical; the } \\
\text { borders are irregular (not smooth); } \\
\text { the color varies; or the diameter is } \\
\text { larger than that of a pencil eraser. } \\
\text { 3. Do you mean Chemo therapy and } \\
\text { radiotherapy, sir? }\end{array}$ \\
\hline $\begin{array}{l}\text { 3. To attend the } \\
\text { patients }\end{array}$ & $\begin{array}{l}\text { 1. Ask questions } \\
\text { 2. Look for clues } \\
\text { 3. Take decision } \\
\text { 4. Giving suggestions }\end{array}$ & $\begin{array}{l}\text { 1. How long have you been suffering } \\
\text { from headache? } \\
\text { 2. Is it a one-sided headache? } \\
\text { 3. Oh, then it is not serious at all. }\end{array}$ \\
\hline
\end{tabular}




\begin{tabular}{|l|l|l|}
\hline & & $\begin{array}{l}\text { 4. Take Napa and take rest, you will } \\
\text { feel better. }\end{array}$ \\
\hline
\end{tabular}

Table-1: Munby's model used for analyzing the necessities of English language proficiency for the medical students.

\section{(b) Lacks}

The second component of the 'Target needs' is to identify the lacks of the learners. To specify the lacks, we first evaluate the level of language proficiency they have already had. Once we can have an idea, we can evaluate how far they need to proceed to fulfill the necessities mentioned above. One target situation necessity might be to answer the scripts in correct English. On the basis of the data collected by a pre-set questionnaire, we can have an idea about how they can comprehend the question and how correctly they answer the question. Seeing the common mistakes (lacks), the course designer can decide what type of material $\mathrm{s} /$ he will choose for the learners to learn writing correct English (necessities).

To determine the lacks of the medical students, I have selected Gonoshasthaya Somaj Vittik Medical College under Gono Bishwabidyalay, one of the prominent private medical colleges in Bangladesh. Here medical students need to complete two semesters of English language course, each semester consists of six months. I selected the students of 1 st semester of this medical college as sample of my research programme. I took 80 out of the whole number of students by random sampling. Out of 80 students, 38 are female and 42 male. Each of them scored Grade A or A+ in their Secondary School Certificate examination and Higher Secondary Certificate examination.

When the information of the data was collected and analyzed, it was found that in the very first question, they made three types of mistakes. Only 34\% students could answer properly.

The first question was: "How long have you been studying in this medical college?" 
$20 \%$ students answered: "I am studying -----" (they did not write: I have been studying.....).

$16 \%$ students answered: "for nine month or three month" (they forgot to add's' after the word month)

$20 \%$ of them mentioned about the duration only though they were instructed to give the answer in complete sentence.

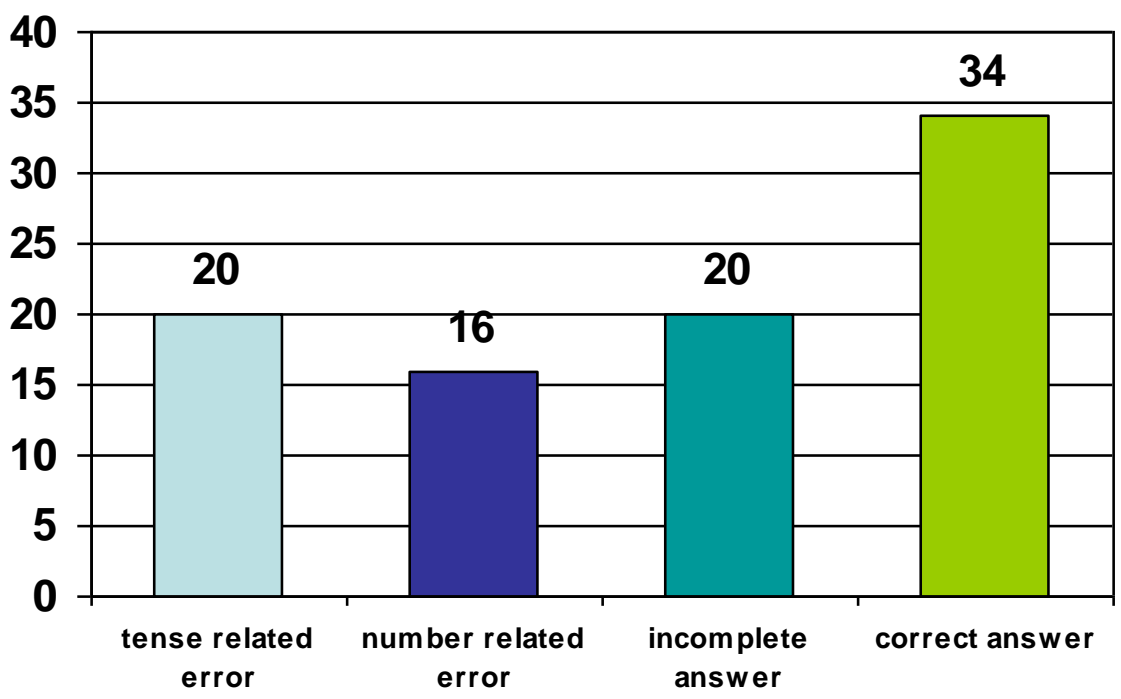

Figure -1 Variable-related error analysis

The second question was: "Why do you want to be a doctor?"

Only $24 \%$ students could answer satisfactorily 


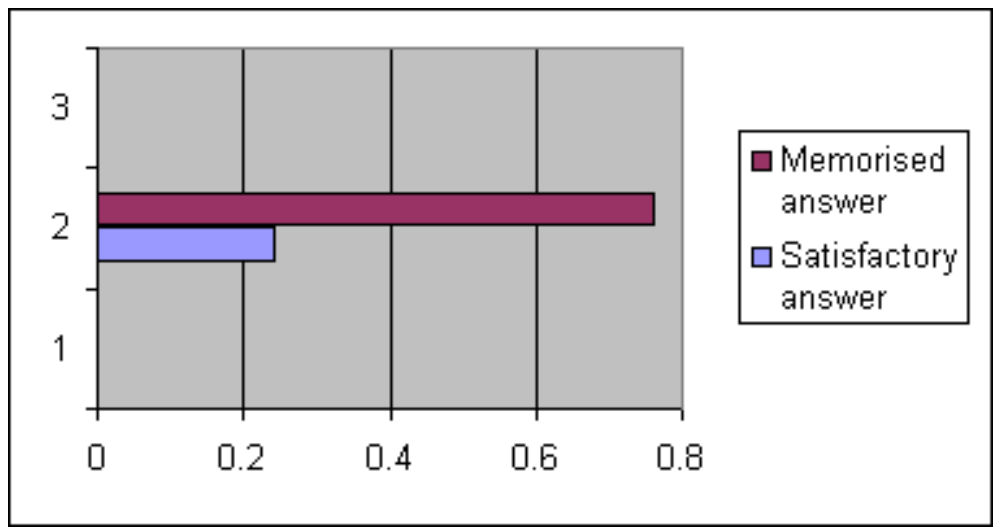

Figure -2 Figure showing the ratio of satisfactory and dissatisfactory answers

The rest of the students just copied one single common answer: 'to serve the poor people.'

But, when they were asked individually the same question in their mother tongue, they answered

'It is the interest of my parents that inspired me to study medicine.'

'My heart bleeds when I see people suffering from diseases. Being a doctor I will serve them.'

'I'll help the poor and I'll never take money from the poor. The rich will feed me and the poor will pray for me.'

'My father is a doctor, so I want to be a good doctor like him.'

These indicate that the learners' ideas are clear, but they could not express them correctly because of their lack in the fluency in English.

So, the target proficiency requires to be matched with the existing proficiency of the learners. The gap between the two can be referred to as the learner's lacks. 


\section{(c) Wants}

The third component of analyzing needs is 'wants'. Learners may have a clear conception of the 'necessities' of the target situation; they will definitely have a view about their 'lacks'. But, it is not impossible that the learner will have their own views and the learners' views may conflict with the perception of other interested parties like the ESP practitioner, sponsors. This means that, for designing a course it is necessary to listen and analyze the opinions of the learners along with the other related opinions. Richterich, R. and Chancerel, J. L. (1980), comment “. . . a need does not exist independent of a person. It is people who build their images of their needs on the basis of data relating to themselves and their environment" (p.29).

There may be a disagreement between 'what one wants' and 'what one should want'. If we analyze the following cases, we will find the differences:

1. Urmi Barua, an internee, will go abroad for higher studies in Cardiology. So, she needs to adjust herself with an English-speaking environment. Under this circumstance, she should target to achieve fluency. But she thinks she needs to improve her knowledge of English grammar. Her logic here is that she must attend and pass a test in order to get selection for the course. In the test, she must prove herself competent in grammar.

2. Rajat Bashak is a medical student. He always needs to go through the text books, journals, and resources from internet in English. He also needs to communicate to foreign teachers and classmates and attend oral tests in English. By the quantitative analysis, Rajat needs to develop his reading since he needs to read frequently. But he thinks he needs to develop his oral competence. He thinks that his strong oral competence will highlight him as a confident person. On the other hand, he can manage, somehow, his reading skill by using a dictionary if he needs. So, Rajat's priority is to develop his speaking skill.

3. Dr. Adnan Chawdhury has recently been selected as a Medical Advisor by a mobile phone company for providing health services over phone. He is selected for his prudence and sharpness in handling the present situation. 
He is fluent, but his spoken English is not accurate. That is why he is sent for a Spoken English course. But, he thinks he speaks good English and that is why he has got a little motivation of the course.

From the case studies above, it is clear that necessities can never be the last words. The learners play a vital role in a learning process. So, the course designers should be aware of evaluating the opinions of the learners that means 'wants'. Phan Le Ha (2005), in his article Munby's 'needs analysis' model and ESP, has criticized by saying "Munby seems to forget the fact that the learners are human beings who can think, feel, sense, see, create and be tired. That is why, in his model, learners are seen as more passive and machine-like beings, who either productively or receptively are pressured by so many artificial factors. He thinks learners only need but do not want. It is really far from the truth. What I have observed so far in language classes proves that 'wants' play a decisive role in mastering a language although 'needs play a key role in learning it' (p.7). So, before analyzing 'needs', a course designer should be particular about the fact that the learners will enjoy the course or whether that will be a burden upon them. Finally, it is possible for a thoughtful ESP teacher to combine the 'necessities' with the 'wants' of the learners.

\section{Learning Needs}

After target needs, we will analyze learning needs. We can consider the whole process of designing an ESP course as a journey. In this process, we can consider the starting point as 'lacks', the destination as 'necessities', and learners' opinions as 'wants'. But, in this case, what will be the route to follow? Actually, how can we reach our destination? - is a question that gives birth to another type of needs known as 'learning needs'. 'Learning needs' refers to the process how learners learn what includes learners' motivation, their knowledge, skills and strategies in learning a language. In fact, the learning needs is a subject highly related to the learners' language problems, their learning objectives, their way of learning etc. An ESP course is really designed by taking cares of the above mentioned components as Hutchinson and Waters (1987) support that the new educational pedagogy emphasizes the importance of the learners and their attitudes to learning. 
Since the ESP learners are adult and more matured, they naturally may have their own opinion. If the syllabus is designed on the basis of the learners' opinion, they will be more motivated. Moreover, when English language materials will be specifically developed from the particular area of learners, they will be interested to learn. In the process of designing the course for the medical students, I have given importance to the 'wants' of the learners. Moreover, the materials I have selected cover the entire area of medical science. Learners' previous knowledge, skills and strategies in learning a language have keenly been observed. Thus I hope, I have analyzed properly both target needs and learning needs for designing the ESP course for the medical students in Bangladesh.

If a course is able to fulfill the requirements and can stimulate interest in learners, it must motivate them highly. This strong motivation will help the course to be easily acceptable. So, to achieve the destination, we must consider learning needs in addition to target needs.

\section{Conclusion:}

ESP is an approach to learning English, which is based on the learners' needs. As a matter of fact, the medical students face problems in all the four skills of language i.e. listening, speaking, reading, and writing. I have noticed that the students have problems in understanding lectures and speeches delivered in English. They hesitate to speak English in the class. Moreover, their reading is not so satisfactory. When they attempt to write, they face various types of problems. Most of them suffer from the lack of adequate vocabulary; their knowledge in the major areas of grammar is not sufficient. I feel that their lack of the knowledge of the language is one of the prime reasons for their not being able to deal with the language correctly. That is why, a particular analysis of target needs and learning needs is essential step to solve the problems of a specific group of learners. 


\section{Works Cited}

Dudley Evans, T., \& St. John, M. (1998). Developments in ESP: A multi-disciplinary approach. Cambridge: Cambridge University Press.

Hutchinson, T. \& Waters, A. (1987). English for specific purposes. Cambridge: Cambridge University Press.

Munby, J. (1978). Communicative syllabus design. London: Cambridge University Press.

Phan Le Ha. (2005). 'Munby's needs analysis model and ESP.' Asian EFL Journal, 6, 1-7.

Richterich, R. \& Chancerel, J. L. (1980). Identifying the needs of adults learning a foreign language. Oxford: Pergamon Press. 